\title{
Low-cost device for active saliva droplet filtration and pathogen inactivation
}

\section{Dispositivo de baixo custo para filtragem ativa de gotículas de saliva e inativação de patógenos}

\author{
Fernando Cardoso Castaldo $^{1}$; Luciane Agnoletti dos Santos Pedotti ${ }^{2}$; \\ Tania Lucia Monteiro ${ }^{3}$; Gabriel Kovalhuk ${ }^{4}$; Rafael Eleodoro de Góes ${ }^{5}$; \\ Isabelly Behlau Spindola ${ }^{6}$; Alan Lugarini ${ }^{7}$; Admilson Teixeira Franco ${ }^{8}$; \\ Antonio Kozlik Junior $^{9}$; Gustavo Henrique Couto ${ }^{10}$
}

\begin{abstract}
This work presents a device capable of performing sanitization in environments using an electrostatic filter and ultraviolet light. Recognized techniques were employed in an innovative and low-cost construction model, like Corona Discharge and UVC germicidal light, using elements of easy acquisition and construction. The device consists of a tube with several electrostatic filters. On one side of the tube, an exhaust fan is installed to collect the air to be disinfected. So the air passes through the tubes with the electrostatic filter, which is responsible for collecting the particles suspended in the passing air, attracting them to the metal surface. Allied with this, UVC lights are also inserted in the structure, ensuring greater effectiveness in decontaminating the air that passes through the tubes. In the posterior side to the exhaust fan, the disinfected air is returned to the original environment. A Fluid dynamics simulation was made to investigate the airflow in a room. Standard strains for antimicrobial susceptibility testing were used for bioaerosols assay. The result is a low-cost equipment with great potential to deactivate several kinds of viruses, most especially the Sars-CoV-2 (Coronavirus), that is the main responsible for the global health crisis, designed to be used indoors with low ventilation.
\end{abstract}

Keywords: COVID-19. Ambient sanitation system. Electrostatic filter. Low-cost.

\section{Resumo}

$\overline{\text { Este trabalho apresenta um dispositivo capaz de realizar a higienização em ambientes utilizando um filtro }}$ eletrostático e luz ultravioleta. Técnicas reconhecidas foram empregadas em um modelo de construção inovador e de baixo custo, como descarga corona e luz germicida UVC, utilizando elementos de fácil aquisição e construção. O dispositivo consiste em um tubo com vários filtros eletrostáticos. Em um dos lados do tubo, um exaustor é instalado para coletar o ar a ser desinfetado. Assim, o ar passa através dos tubos com o filtro eletrostático, que é responsável pela coleta das partículas suspensas neste ar, atraindo-as para a superfície metálica. Aliado a isto, também são inseridas luzes ultravioleta na estrutura, garantindo maior eficácia na descontaminação do ar que passa entre os tubos. No lado posterior ao exaustor, o ar desinfetado é devolvido ao ambiente de origem. Uma simulação de dinâmica de fluidos foi feita para investigar o fluxo de ar em uma sala. As cepas padrão para teste de susceptibilidade antimicrobiana foram usadas para o ensaio de bioaerossóis. O resultado é um equipamento de baixo custo com grande potencial para desativar vários tipos de vírus, especialmente o Sars-CoV-2 (Coronavirus), que é o principal responsável pela crise sanitária mundial, projetado para ser utilizado em ambientes internos com baixa ventilação.

Palavras-chave: COVID-19. Sanitizador de ambientes. Filtro eletrostático. Baixo custo.

\footnotetext{
${ }^{1}$ Prof. Dr., Electronics Academic Department, UTFPR, Curitiba, PR, Brasil, E-mail: castaldo@utfpr.edu.br

2 Prof. Dr., Electronics Academic Department, UTFPR, Curitiba, PR, Brasil, E-mail: lucianesantos@utfpr.edu.br

${ }^{3}$ Prof. Dr., Electronics Academic Department, UTFPR, Curitiba, PR, Brasil, E-mail: tmonteiro@utfpr.edu.br

${ }^{4}$ Prof. Msc., Electronics Academic Department, UTFPR, Curitiba, PR, Brasil, E-mail: kovalhuk@utfpr.edu.br

${ }^{5}$ Prof. Dr., Electronics Academic Department, UTFPR, Curitiba, PR, Brasil, E-mail: rgoes@utfpr.edu.br

${ }^{6}$ Academic Mechanical Engineering, CERNN, UTFPR, Curitiba, PR, Brasil, E-mail: isabellyspindola@ alunos.utfpr.edu.br

${ }^{7}$ Msc. Mechanical Engineering and Researcher, CERNN, UTFPR, Curitiba, PR, Brasil, E-mail: alansouza@utfpr.edu.br

${ }^{8}$ Prof. Dr., Postgraduate Program PPGEM-CT, CERNN, UTFPR, Curitiba, PR, Brasil, E-mail: admilson@utfpr.edu.br

${ }^{9}$ Prof. B.Sc., Mechanical Academic Department, UTFPR, Curitiba, PR, Brasil, E-mail: kozlik@utfpr.edu.br

${ }^{10}$ Prof. Dr., Department of Chemistry and Biology, UTFPR, Curitiba, PR, Brasil, E-mail: gustavocouto@utfpr.edu.br
} 


\section{Introduction}

The global crisis with the outbreak of the coronavirus COVID-19 (Sars-CoV-2) brought down the stock exchange worldwide, caused lockdowns and could lead to the collapse of public health systems in several countries. Until a vaccine is developed and made available, prophylaxis against the pandemic involves palliative measures such as symptomatic medical prescription and, above all, preventive measures. In this sense, many actions are oriented to sanitization of the hands in particular. Surfaces contaminated with the virus, which can even remain active for hours, are the potential infectious elements. Recent literature reports sanitizing measures to eliminate the virus employing chemical disinfectants (KAMPF et al., 2020).

Microdroplets of saliva are expelled into the air when we talk, cough, or sneeze and are also known as Flügge droplets. These particles contain pathogens and vary in diameter from 0.1 to $2 \mathrm{~mm}$ and can go to the ground or evaporate and remain in suspension in the air of closed environments for long periods, being responsible for the spread of diseases transmitted via the respiratory system by inhalation (HARE, 1964; MAZUMBAR, 1995).

The larger saliva droplets, with about 100 micrometers or more, quickly fall and contaminate nearby objects. People who touch these surfaces then come into contact with the virus. The smaller droplets, with varying sizes, can even assume microscopic dimensions, will remain suspended in the air for several hours, and to move over great distances (VIEIRA et al., 2020). These microdroplets in suspension have a tremendous infectious capacity, especially in places of great circulation of people; it is enough to inhale. On average, COVID19 measures 100 nanometers. One 10 micrometer saliva droplet can accommodate thousands of active viruses (VIEIRA et al., 2020).

Thus, frequent sanitization measures are indispensable in places with the movement of people, for example, hospital receptions and public places with high flow and waiting rooms. Such measures include the spraying of sanitizers, the use of ultraviolet light, and ozone (HUDSON; SHARMA; VIMALANATHAN, 2009). Usually, these are methodologies that require the empty room, for safety measures. Most hospital sanitization protocols are standardized and adopt well-established procedures (ANVISA, 2020). For these special situations and considering that we will have to live with virus's presence in the country and the world for some uncertain time, some more effective prophylactic measures must be implemented.

Equipment developed to clean the air is common and can be found commercially, but the cost of large-scale production is inaccessible, especially in most impoverished countries. This work refers to a low-cost device responsible for cleaning the air using an electrostatic filter. This type of filter is capable of collecting from the air distinct types of particles such as smoke, dust, water, and other harmful contaminants. When crossing an ionized field, such particles receive electrical charges which aligning their poles. Thus, they are attracted to a collecting plate of reverse polarity, so that the air that crosses through the flow can leave with virtually no particles (LOWER, 2020; MILAN, 2018).

As the filter attracts these particles to a heated surface, viruses that may be suspended are also collected. It is known that several enveloped viruses, such as the Sars$\mathrm{CoV}-2$, die at temperatures above $56{ }^{\circ} \mathrm{C}$ (WHO, 2020). Thus, the device, besides filtering the air, is responsible for the sanitization of several types of viruses, since it has a heating plate on its surface whose temperature can be adjusted and consequently, minimizing the possibility of transmission of diseases arising in this way. The principle of inactivation of many types of viruses present in the air and the manufacturing process of this low-cost equipment will be presented in this work, with as a means to help to help combat diseases that can be transmitted by air.

\section{Literary advance research}

Similar devices were researched as the one presented in the patent US6245131 - ELECTROSTATIC AIR CLEANER described in Rippelmeyer and Mcelroy (2001), where an electrostatic air cleaner system is presented for installation in an air circulating process, including several sensors to control the filtered airflow. This kind of Electrostatic air cleaners is widely used in air circulating systems. This equipment has constructive details that require sensors that make the final product more expensive and are assembled in a cabinet. The inventor was inspired by several similar patents, suggesting an innovative constructive form (RIPPELMEYER; MCELROY, 2001).

In the patent US4919693 - ELECTROSTATIC AIR CLEANER described in Olney (1990), the inventor presents a filter for automotive applications with coal filter but presented a size applicable to small areas. 
The main object of this invention is to provide a new and improved electrostatic air cleaner which is susceptible to a low cost of manufacture with regard to both materials and labor. This equipment may be powered by an adaptor connected to a cord and engaged with a $12 \mathrm{~V}$ power socket, that is, adapted for use in vehicles (OLNEY, 1990). No studies were found on the efficiency of this two patented equipment.

Innovations in the way airflow is maintained for filtration have also been suggested, as in Griffiths and Gay (2005), where a device featuring two $12 \mathrm{kV}$ spiral-shaped electrodes where a fan supplies the device's airflow and operates at over $99 \%$ efficiency up to $3 \mathrm{~m} / \mathrm{s}$, however, features a filter that requires periodic maintenance and regular replacement.

Devices developed to clean and purify the air have also been specified, as in Gefter (2009), whose purpose besides purifying the air, also provides filtration of the residues that are generated during this process, such as ozone $\left(\mathrm{O}_{3}\right)$.

What makes the proposed device different from similar existing devices is its low-cost production, simplicity, and installation robustness. The proposed device is a utility model that uses several techniques already approved and efficient but using a fast process construction and accessible and easy acquisition materials. The purpose of this device is:

(1) to clean the air of particles in the micrometer range;

(2) to eliminate pathogenic elements harmful to health such as viruses that transit using water particles, saliva droplets, and dust.

There are commercial equipment for a similar operation. However, the purchase cost is much more expensive when compared to the proposed equipment, which can be manufactured with pieces of equipment that are easy to purchase locally. What makes this equipment attractive is precisely it's low-cost when compared to existing commercial equipment. The proposed equipment was produced at about \$ USD 160 using commercial raw material. This cost will drop when it can be produced on a large scale. Table 1 summarizes the average price of similar commercial devices.

\section{Methodology}

The equipment has a simple and robust construction, in carbon steel or stainless steel with laser-cut acrylic tops and an exhaust fan to propel the airflow.
Table 1 - Price of similar commercial devices

\begin{tabular}{clc}
\hline Item & \multicolumn{1}{c}{ Description } & \multicolumn{1}{c}{$\begin{array}{c}\text { Price } \\
\text { (\$ USD) }\end{array}$} \\
\hline \multirow{3}{*}{$1 \quad \begin{array}{l}\text { Filter Queen Defender } \\
\text { Air Purifier HEPA Air } \\
\text { Cleaner FDA Recognized } \\
\text { Class II Medical Device }\end{array}$} & \$799.00 \\
& Blueair Classic 680i Air \\
& Purifier for Home with & \\
2 & $\begin{array}{l}\text { HEPASilent Technology } \\
\text { and DualProtection Filters } \\
\text { for Relief From Allergies, }\end{array}$ & \$1,599.00 \\
& $\begin{array}{l}\text { Pets, Dust, Asthma, } \\
\text { Odors, Smoke - Large Rooms }\end{array}$ & \\
& $\begin{array}{l}\text { Molekule Air Large Room } \\
\text { Air Purifier with PECO } \\
\text { Technology for Allergens, } \\
\text { Pollutants, Viruses, }\end{array}$ & \\
Bacteria, and Mold, Silver & \\
\hline
\end{tabular}

Source The authors.

The fixation can be done by a tie for easy installation, but other means can be used. The cylindrical shape is suitable because it corresponds to the usual shape of commercial hoods. It requires low-cost electronics, consisting of an oscillator, step-up transformer, and voltage multiplier. Also, a heating element that for convenience can be the a flexible heating component to fit the body of the equipment. A thermal insulation blanket isolates the assembly. The set is electrically shielded and connected to ground potential, to ensure safety and avoid detachment of electrical charges and ions. Figure 1 shows this conceptual proposal. Figure 2 shows the finished device project.

Particulate matter dispersed in the environment is a mixture of particles suspended in the air. An aerosol is a complex mixture of liquids and solid particles suspended in a gaseous medium, usually atmospheric air. The size of the particles that constitute the aerosol is in the range of 0.002 to 100 micron. According to the International Organization for Standardization (ISO) particles below $40 \mathrm{~nm}$ are considered nanoparticles. The interest in air purification through the removal of nanoparticles is based on public health issues. The electrostatic precipitator is one of the most common devices for particle and aerosol filtration control. It has been used for over a century in the industry to remove particles and volatile waste to avoid air pollution. It is also used in the recovery of dispersed materials in aerosols (FALAGUASTA, 2005; MILAN, 2018; RIPPELMEYER; MCELROY, 2001). 
Figure 1 - Conceptual proposal of the collector: internal (left) and external (right)

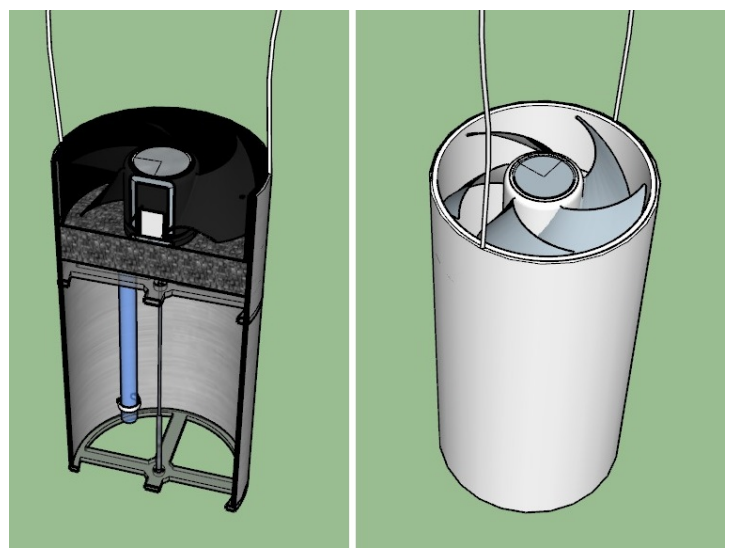

Source: The authors.

Figure 2 - Finished ideal layout

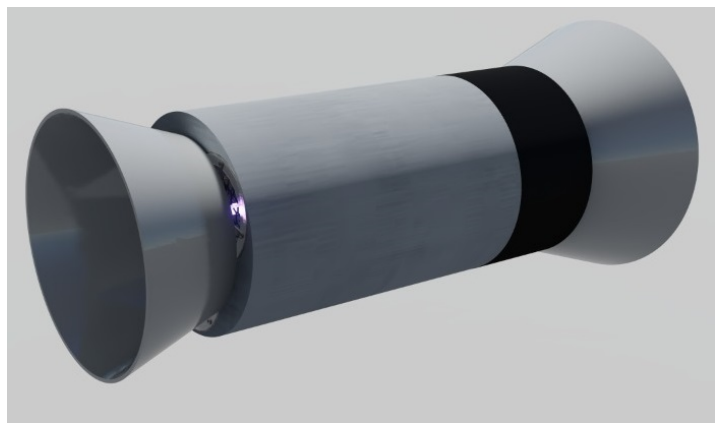

Source: The authors.

Regarding the operation, it acts on the suspended particles by supplying an electrical charge to them, and in the sequence, being imprisoned by an opposing charge electrode. The charge supply is provided by the Corona discharge, which occurs between two conductors subjected to a high difference in potential and atmospheric pressure. In this process, ions are generated from the material (usually air) that surrounds the conductors. Corona discharge can be positive or negative, depending on the polarity of the electrodes. The positive system was chosen because it involves a gaseous process (MEIRA, 2009).

In situ experiments with atomized water flow in a domestic ultrasonic vaporizer demonstrates the effectiveness of capturing water droplets. Considering that the relative electric permissiveness of the water is 80 , the field is intensified inside the droplet, further increasing the efficiency of the system. Lower operating voltages can then be used. It is ensured that the flow of water droplets flowing through the pipe can be blocked electrostatically. The electrostatic process, based on corona discharge, due to the high voltage required to produce the loads, gener- ates ozone as a by-product. Studies suggest that this gas, in concentrations above $0.01 \mathrm{ppm}$ is harmful to human health (FALAGUASTA, 2005), therefore, for a system that intends to be operated continuously this gas must be monitored. An appropriate sensor for this task will be applied.

Of course, other particulates, dust, for example, can affect this approach, but we must consider that we want to protect the environment that is relatively free of dust, which is a valid consideration for waiting rooms, hospital rooms, among others. Another approach to mitigate the production of ozone refers to the use of catalytic reactors (RANGEL, 1997), to be further investigated, such as activated carbon filters involving the central electrode.

Technically, electrical loads can flow from a conductor through the power of the tips, thus reaching the dielectric stiffness limit of the air $\left(3 \times 10^{6} \mathrm{~V} / \mathrm{m}\right)$. The ozone generated in this process must be appropriately destroyed by UV lights with a specific wavelength that can ranging from 250 to $260 \mathrm{~nm}$ (SUMMERFELT, 2003).

\section{Device description}

The proposed device is made of $0.5 \mathrm{~mm}$ carbon steel and $10 \mathrm{~mm}$ thick acrylic tops with laser-cut castings. Central electrode is composed by a $2 \mathrm{~mm}$ diameter aluminum rod and $0.25 \mathrm{~mm}$ diameter tungsten wire wrapped in a helicoidal structure, to promote the charge concentration and favor corona discharge. Insulated connections and high voltage cables with polyethylene hose reinforcement are used.

A low-cost electronics composed of a self-powered current-mode oscillator circuit, a step-up transformer (flyback-15 kV), and a 10-stage voltage multiplier with approximately $100 \mathrm{pF}$ capacitive reactance and maximum operating voltage of $75 \mathrm{kV}$. For the heating system, a flexible $450 \mathrm{~W} / 127 \mathrm{~V}$ resistor is attached to the outside of the collector. A fiberglass blanket thermally insulates the assembly so as not to heat the environment.

Temperature control and high voltage generation systems was implemented in the project. The correct sizing of the electronics should meet the demand or charging curve when the system is in operation, providing the necessary electrical loads. Furthermore, when considering a small electrostatic charge, depending on the number of droplets present in the medium, low-power electronic systems can be used. The developed device is shown in Figures 3 and 4. 
Figure 3 - Built prototype installed in a room

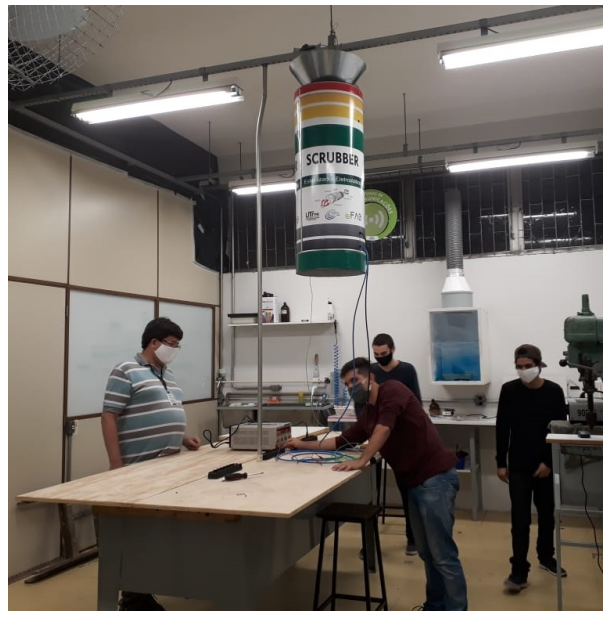

Source: The authors.

Figure 4 - Prototype with UVs On

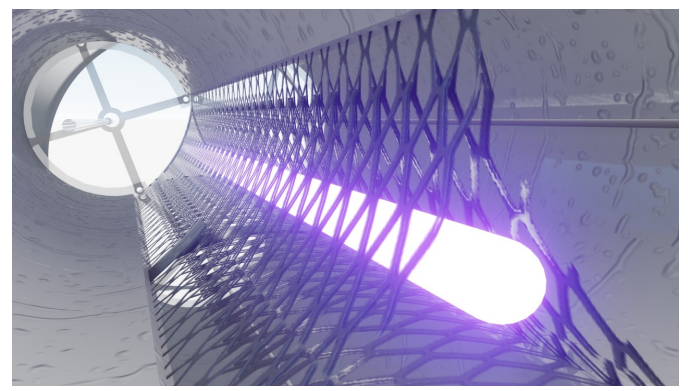

Source: The authors.

UVC lamp was installed inside the device, providing greater efficiency in sanitizing the air to be cleaned and plays a crucial role in eliminating the ozone generated during electrostatic cleaning, providing the return of air to the environment healthy and properly sanitized (FARREN; YERALAN, 2014; HAVENS; HENNICK, 2012; SHAM, 2002; VIG; LEBUS, 1976).

The material used to produce this prototype costs less than \$ USD 160.00. In other words, the product costs around $5 \times$ cheaper than those available on the market. It is known that the manufacturing price does not express the commercial value where other factors such as advertising, research hours, among others, are taken into account. However, if the device is manufactured on a large scale, this cost tends to fall considerably.

\section{Results}

The efficiency of an electrostatic collector refers to the ratio between the number of particles retained and entering the system. For usual systems, efficiency is a function of the mass of the particle and its diameter, flow velocity, and density of the flow, electrical field applied, and charge retention time of the nanoparticles.
There is an increase in removal efficiency with the increase of the electric field for all speeds (MEIRA, 2009). For certain electric field values, it was possible to obtain efficiencies above $99 \%$ for all particle diameters. Increasing the flow velocity required the application of higher voltages. Typically, about $5 \mathrm{kV} / \mathrm{cm}$ for flow velocity of $8 \mathrm{~cm} / \mathrm{s}$, as shown in Figure 5.

Figure 5 - Fractional efficiency for $8 \mathrm{~cm} / \mathrm{s}$ speed

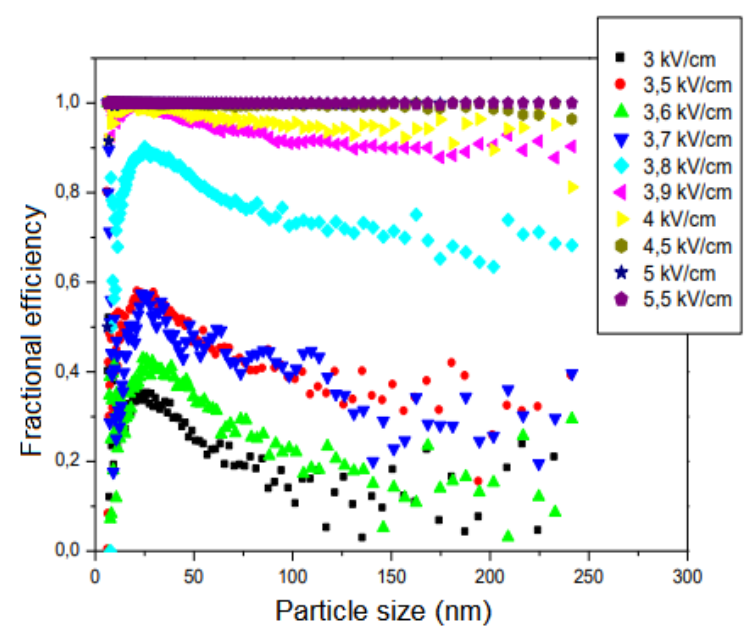

Source: Adapted from Meira (2009).

Thus, the voltage used in the ionizer of the equipment developed meets the specifications defined in the graph, that is, the ionization voltage is $5 \mathrm{kV} / \mathrm{cm}$ for flow velocity less than $8 \mathrm{~cm} / \mathrm{s}$. Tests made with water sprayed in the equipment's atmosphere showed that the developed device managed to collect practically all the water sprayed. This is promising when bacteriological tests will be done in the next step.

The proposed system must be validated for operation in public environments. One of the propositions suggests tests for capturing suspended particles associated with particle counting in a controlled environment according to the flow rate of the collector system. The decay rates of particle concentration in the medium will indicate system efficiency. Another test employs markers, still to be defined, simulating the presence of pathogens and their capture time. The measurement process must be accompanied by monitoring of the various parameters (temperature, humidity, airflow, ozone content, etc.) throughout the environment during the experiments.

Furthermore, the process must be statistically validated to estimate collection times and efficiency for subsequent sizing in real applications. This study requires special formulations of fluid dynamics, parameter control, and statistical analysis, as well as the development of a design methodology for collection systems in real environments. 


\section{Fluid dynamics simulation}

A computational fluid dynamics analysis of the airflow in a room was performed using Ansys Fluent ${ }^{\circledR}$. Timeaveraged conservation equations of mass and momentum, along with the k- $\omega$ STT turbulence model, were solved by the finite volume method. A normalized convergence criterion of $10^{6}$ was enforced for all equations. The room dimensions are shown in Figure 6. Only half of the room was modeled since a symmetry condition was imposed in the diagonal plane.

Figure 6 - Computational fluid dynamics: physical domain.

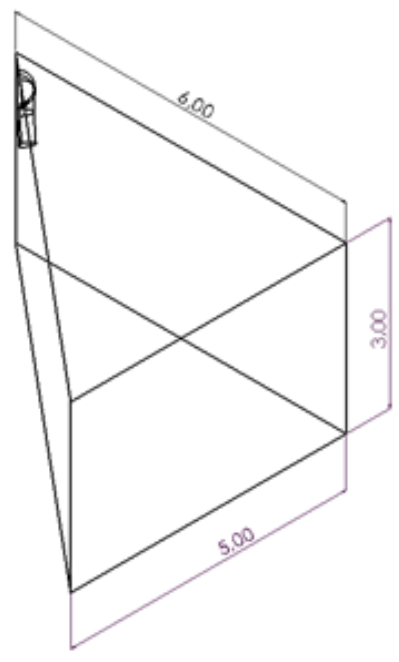

Source: The authors.

The boundary condition for all walls was no-slip. Approximately 4.5 million volume elements were built during the meshing process, with the smallest length of $9.87 \mathrm{~mm}$. The time-stepping method was constant. However, as the simulation progressed, higher time-steps could be set. They started with $0.0003 \mathrm{~s}$, and towards the end of the simulation, the time step was $0.15 \mathrm{~s}$. A total of $17 \mathrm{~s}$ was solved for. The collector's nozzle had a diameter of $40 \mathrm{~cm}$ and was defined as a pressure outlet. The collector's ventilation opening had a diameter of $10 \mathrm{~cm}$ and was defined as a velocity inlet of $17.73 \mathrm{~m} / \mathrm{s}$.

Figure 7 shows streamlines in the diagonal plane. In the ventilation direction, the flow has a high velocity and circulates along the diagonal plane. This is considered to be a primary flow. In Figure 8, streamlines on a perpendicular plane are shown. The stream function is considerably lower than in the diagonal plane, which means this is a secondary flow. A stochastic particle tracking (random walk) was implemented to evaluate typical clean up times in different regions in the room. A sample of ten massless particles was randomly placed within each region, and their times-to-outlet were measured. Their instantaneous velocity was equal to the local mean flow velocity, superposed with random perturbations (proportional to the local turbulent intensity). The regions middle-center and bottom are more exposed to the primary flow, so the clean up is relatively fast. The most critical region is the middle-corner, which is located near the walls, at half the room height. The secondary flow moves the particles in this region to the main current and then swept away from the room. Due to this dependence on the secondary flow, the average time to clean up the middle-corner region is around 9 minutes. Table 2 summarizes the stochastic particle tracking method and the time spent in each region.

Table 2 - Clean up times with the stochastic particle tracking method.

\begin{tabular}{ccc}
\hline Region & $\begin{array}{c}\text { Average } \\
\text { [min] }\end{array}$ & $\begin{array}{c}\text { Standard } \\
\text { deviation [min] }\end{array}$ \\
\hline Middle-center & 4.41 & 3.20 \\
Middle-corner & 9.00 & 4.95 \\
Bottom & 5.01 & 3.21 \\
\hline
\end{tabular}

Source: The authors.

Figure 7 - Computational fluid dynamics: streamlines in the diagonal plane.

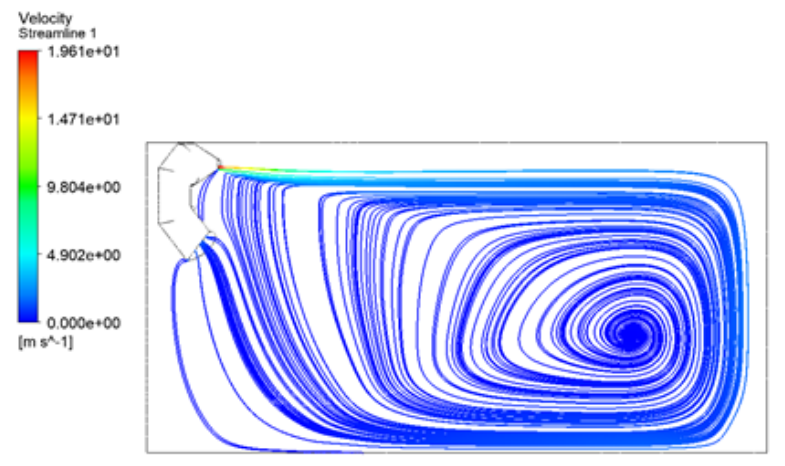

Source: The authors.

Figure 8 - Streamlines in a perpendicular plane.

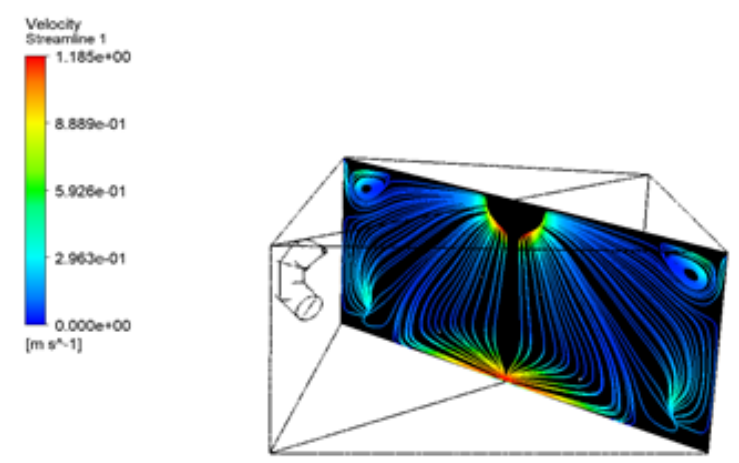

Source: The authors. 


\section{Bioaerosol tests}

Bioaerosol tests will be performed initially with $E s$ cherichia coli ATCC 25922, Staphylococcus aureus ATCC 29213, and Pseudomonas aeruginosa ATCC 27853, standard strains for antimicrobial susceptibility testing, which are commonly found in indoor and hospital environments. Strains will be cultivated separately in trypticase soy broth (TSB) at $37^{\circ} \mathrm{C}$ for $18 \mathrm{~h}$ in a shaking incubator followed by centrifugation to harvest the cells to obtain a suspension in deionized water with a concentration of $10^{3}$ cells per $\mathrm{mL}$. Test bacteria will be aerosolized at a specific volume/min in which the aerosol stream will pass through the system. Petri dishes containing trypticase soy agar (TSA) will be placed at the bottom of the device to collect any viable bioaerosol particles. Inactivation efficiency will be determined in terms of colony-forming unit (CFU) log reduction as the difference between plate counting with the device operating in its active mode (high temperature and voltage) in contrast to the passive mode (control). Because sanitization is intended to reduce most recognized pathogenic microorganisms, it can be inferred that this sanitization device should minimize the viability of SARS-CoV-2, a type of lipid coronavirus that is less resistant to germicidal chemicals when compared to the bacterial strains to be tested in further studies (CENTER FOR DEVICES AND RADIOLOGICAL HEALTH, 2020).

\section{Discussion}

The device has technical potential to achieve the following objectives: promote air cleaning in up to $99 \%$ of the existing particles; kill viruses or other organics harmful to human health through the collection surface heated by a plate with adjustable temperature; simple and short production time for large scale and low-cost.

\section{Conclusion}

This work presented the prototype of a low-cost saliva microdroplets collecting device still under development, as a possible active tool in the fight against airborne diseases, such as COVID-19.

The fluid simulation tests in the proposed environment were promising and motivate us to continue the development of the proposed equipment. The bacteriological tests that will be developed are already properly identified.

Similar academic works, as SIM (2015), suggest the insertion of chemicals to help in the decontamination of the air that passes through the equipment. This alternative will be studied as soon as the efficiency tests are finished.

For testing the final prototype, the design and dimensioning of the electronic drive must be discussed, and a design methodology for these devices must be developed, mainly for safety. The load curves of the collection systems should also be discussed. Efficiency tests still need to be done to validate theoretical efficiency. For this, the project still needs financial resources for its completion.

In future works, it is intended to develop a special format of central electrode other than the cylindrical one to minimize the necessary operating voltage and consequently reduce the amount of ozone generated. Positive or negative charge systems as well as charging strategies can be investigated.

\section{References}

ANVISA. Manual de segurança hospitalar. Brasília: Anvisa, 2020. Available from: <http://portal:anvisa:gov: br/documents/33852/271855/Seguran\%C3\%A7a+no+ ambiente+hospitalar/473c5e32025a4dc2ab2efb5905d7 233a >. Access in: Apr. 2020.

CENTER FOR DEVICES AND RADIOLOGICAL HEALTH. Enforcement Policy for Sterilizers, Disinfectant Devices, and Air Purifiers During the Coronavirus Disease 2019 (COVID-19) Public Health Emergency. [Whashington]: FDA, 2020. Available from: <https://www:fda: gov/regulatory-information/search-fda-guidance-docum ents/enforcement-policy-sterilizers-disinfectant-devices -andair-purifiers-during-coronavirus-disease $>$. Access in: Apr. 2020.

FALAGUASTA, M. C. R. Estudo do Desempenho de um Precipitador Eletrostático operando na captura de partículas submicrométricas e nanométricas, Tese (Doutorado), UFSCAR, São Carlos, SP. 2005.

FARREN, A; YERALAN, S. Compositions and Methods for UV Sterilization. US 2014/0161663 A1. Deposit: 26 Nov. 2013. Granting: 12 June 2014.

GEFTER, P.; KLOCHKOV, A.; MENEAR, JOHN E.; NELSEN, LYLE D. Clean corona gas ionization. US8460433B2. Deposit: 24 Apr. 2009. Granting: 09 Aug. 2012. 
GRIFFITHS, G. S.; GAY, G. N. W. Norman Walter. Air Cleaning Device. EP1169131B1. Deposit: 12 Apr. 2000. Granting: 22 June 2005.

HARE, R. The Transmission of Respiratory Infections. Proceedings of the Royal Society of Medicine, [London], v. 57, n. 3, p. 221-230, 1964.

HAVENS, W. H; HENNICK; R. J. Sterilization Apparatus. US 8203124 B2. Deposit: 27 Abr. 2007. Granting: 19 June 2012.

HUDSON, J. B.; SHARMA, M.; VIMALANATHAN, S.; Development of a practical method for using ozone gas as a virus decontaminating agent, ozone: Science \& Engineering, v. 31, n. 3, p. 216-223, 2009. DOI: 10.1080/01919510902747969. Access in: Apr. 2020.

KAMPF, G.; TODT, D.; PFAENDER, S.; STEINMANN, E. Persistence of coronaviruses on inanimate surfaces and their inactivation with biocidal agents. Journal of Hospital Infection, London, v. 104, n. 3, p. 246-251, 2020. Available from: <https://doi:org/10:1016/j:jhin:2020:01:022>. Access in: Apr. 2020.

LOWER, A. What Is An Electrostatic Air Filter? Second Nature, [S. l.], 2020. Available from: <https://www.seco ndnature.com/blog/around-the-house/electrostatic-air-fil ters $>$. Access in: Apr, 2020.

MAZUMBAR, P. M. H. Species and Specificity: An Interpretation of the History of Immunology. Toronto: University of Toronto, 1995.

MEIRA, C. R. Desempenho de um precipitador eletrostático operando na remoção de nanopartículas de aerossóis. 2009. Dissertação (Mestrado) - Universidade Federal de São Carlos, São Carlos, 2009.

MILAN, A. What is the electrostatic air cleaner, and how it works? Air Purifier First, [S. l.], 8 Jan. 2018. Available from:: <https://www.airpurifierfirst.com/blog/electrosta tic-air-cleaner-works/>. Access in: Apr, 2020.

OLNEY, Richard A. Electrostatic Air Cleaner. US4919693. Deposit: 29 Mar. 1989. Granting: 24 Apr. 1990.
RANGEL, M. C. Membranas Inorgânicas e reatores catalíticos. Química Nova, São Paulo, v.20, n.5 Sept./Oct. 1997.

RIPPELMEYER, D. M.; MCELROY, J. W. Electrostatic Air Cleaner. US6245131. Deposit: 02 Oct. 1998. Granting: 12 June 2001

SHAM, J. C. K.; Ultraviolet Air Purifier. US 6464760 B1. Deposit: 27 Sept. 2000. Granting: 15 Oct. 2002. US 6464760 B1

SIM, K. M.; PARK, H. S.; BAE, G. N.; JUNG, J. H. Antimicrobial nanoparticle-coated electrostatic air filter with high filtration efficiency and low pressure drop. Science of the Total Environment, Amsterdam, v. 533, p. 266-274, 2015. Available from: <http://dx:doi:org/10:1016/j: scitotenv:2015:0:003>. Access in: Apr. 2020.

SUMMERFELT, S. T. Ozonation and UV irradiation - An introduction and examples of current applications. Aquacultural Engineering, London, v. 28, n. 1/2, p. 21-36, 2003.

VIEIRA, J. M.; Ricardo O. M. P.; Hannas, C. M.; Kanadani, T. C. M.; Prata T. S.; Kanadan, F. N. What do we know about COVID-19? A review article. Revista da Associação Médica Brasileira, São Paulo, v. 66, n. 4, p. 534-540, 2020.

VIG, J.; LEBUS J., UV/Ozone Cleaning of Surfaces. IEEE Transactions on Parts, Hybrids, and Packaging, Canadá, v. 12, n. 4, p. 365-370, Dec. 1976. Doi: 10.1109/TPHP.1976.1135156. Access in: Apr. 2020.

WHO - WORLD HEALTH ORGANIZATION. First data on stability and resistance of SARS coronavirus compiled by members of WHO laboratory network. 2020. Available from: <https://www:who:int/health-topics/severe-acu te-respiratorysyndrome/technical-guidance/laboratory /first-data-onstability-and-resistance-of-sars-coronavir us-compiledby-members-of-who-laboratory-network $>$. Access in: Apr. 2020. 